INTER NATIONAL MONETARY FUND

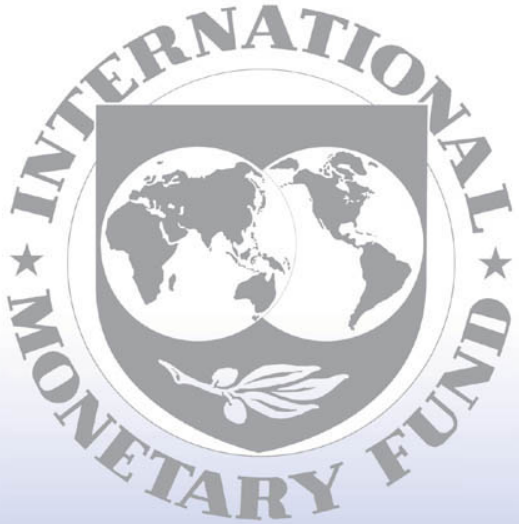

Staff

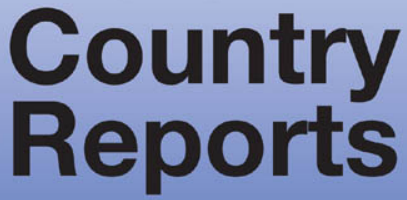




\section{Nepal: Report on Observance of Standards and Codes- Fiscal Transparency Module}

This Report on the Observance of Standards and Codes on Fiscal Transparency for Nepal was prepared by a staff team of the International Monetary Fund as background documentation for the periodic consultation with the member country. It is based on the information available at the time it was completed on September 27, 2007. The views expressed in this document are those of the staff team and do not necessarily reflect the views of the government of Nepal or the Executive Board of the IMF.

The policy of publication of staff reports and other documents by the IMF allows for the deletion of market-sensitive information.

To assist the IMF in evaluating the publication policy, reader comments are invited and may be sent by e-mail to publicationpolicy@imf.org.

Copies of this report are available to the public from

International Monetary Fund • Publication Services

700 19th Street, N.W. • Washington, D.C. 20431

Telephone: (202) 6237430 • Telefax: (202) 6237201

E-mail: publications@imf.org • Internet: http://www.imf.org

Price: $\$ 18.00$ a copy

\section{International Monetary Fund Washington, D.C.}


This page intentionally left blank 
INTERNATIONAL MONETARY FUND

NEPAL

\title{
Report on the Observance of Standards and Codes (ROSC) Fiscal Transparency Module
}

\author{
Prepared by the Fiscal Affairs Department \\ Approved by David Burton and Teresa Ter-Minassian
}

September 27, 2007

\section{EXECUTIVE SUMMARY}

This report provides an assessment of fiscal transparency practices in Nepal in relation to the requirements of the IMF Code of Good Practices on Fiscal Transparency-Declaration on Principles based on discussions with the authorities, the authorities' response to the IMF fiscal transparency questionnaire, and other documents provided by the authorities. The $I M F$ Manual on Fiscal Transparency (http://www.imf.org/external/np/fad/trans/manual/) should be consulted for an explanation of the terms and concepts discussed in this report.

The Government of Nepal has made some progress in recent years towards enhanced fiscal transparency, particularly in relation to availability of fiscal information. However, further major reforms need to be adopted in order to bring Nepal up to international standards of fiscal transparency, a goal to which the authorities indicated their commitment.

Although the existing framework of laws, rules, and regulations is elaborate, fiscal activities are not comprehensively covered in the current budget. There is also a wide gap between the framework and the effective implementation of the individual laws and regulations.

Limitations in the area of human resources pose major challenges to the authorities in closing this gap, and capacity building should be of high priority. In addition, a number of significant issues in the budgeting, accounting, and auditing systems that adversely affect transparency have been identified and remedial measures suggested. For example, transparency would be substantially improved by adopting international concepts of central and general government in preparing, executing, and reporting fiscal activities. Furthermore, analytical data supporting the assumptions underlying the budget should be published, including full information on contingent liabilities and quasi-fiscal activities.

This report provides a detailed list of necessary steps to enhance fiscal transparency in the short and medium terms.

Reports on Standards and Codes (ROSCs) are undertaken on a voluntary basis by Fund Member countries. Publication of the ROSC occurs with the Member's agreement and after prior notification to the Executive Board of the IMF. 


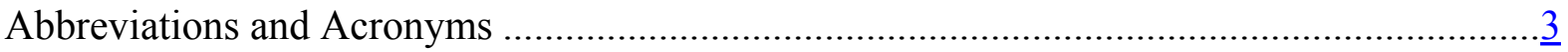

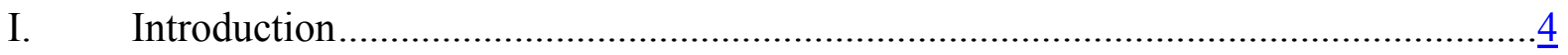

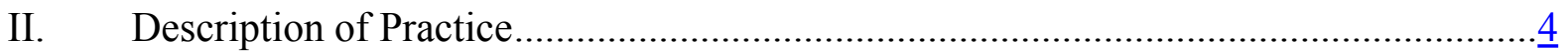

A. Clarity of Roles and Responsibilities..........................................................

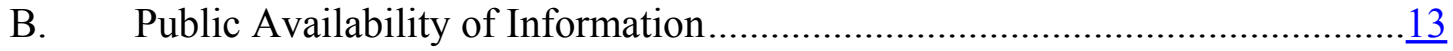

C. Open Budget Preparation, Execution, and Reporting ….............................15

D. Independent Assurances of Integrity .......................................................

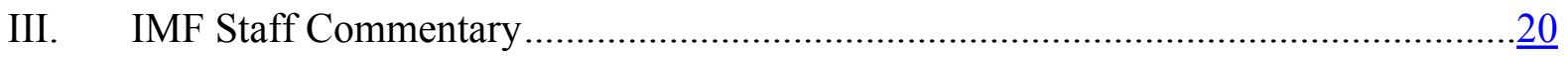

Boxes

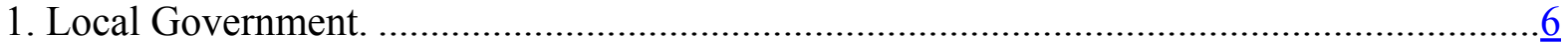

2. Government Regulation of the Private Sector ............................................................ 9

3. Anti-corruption Measures .................................................................................. 


\section{AbBreviations AND ACRONYMS}

\begin{tabular}{|c|c|c|}
\hline $\mathrm{AG}$ & Auditor General & www.oagnep.gov.np \\
\hline AWF & Army Welfare Fund & \\
\hline BOT & Build, Operate and Transfer & \\
\hline CBS & Central Bureau of Statistics & \\
\hline CIAA & Commission for the Investigation of Abuse of Authority & www.ciaa.gov.np \\
\hline $\mathrm{COA}$ & Chart of Accounts & \\
\hline COFOG & Classification of Functions of Government & \\
\hline DDC & District Development Council & \\
\hline DG & Director General & \\
\hline DTCO & District Treasury and Control Office & \\
\hline FCGO & Financial Comptroller General Office & www.fcgo.gov.np \\
\hline FAD & Fiscal Affairs Department & \\
\hline FY & Fiscal Year & \\
\hline GDP & Gross Domestic Product & \\
\hline GFS & Government Finance Statistics & \\
\hline GDDS & General Data Dissemination Standards & \\
\hline ICAN & Institute of Chartered Accountants of Nepal & \\
\hline IMF & International Monetary Fund & \\
\hline IRD & Inland Revenue Department & www.ird.gov.np \\
\hline LTO & Large Taxpayer Office & \\
\hline MOF & Ministry of Finance & www.mof.gov.np \\
\hline MTEF & Medium Term Expenditure Framework & \\
\hline NPC & National Planning Commission & www.npc.gov.np \\
\hline NPR & Nepali Rupees & \\
\hline NRB & Nepal Rastra Bank & www.nrb.org.np \\
\hline NVC & National Vigilance Centre & www.nvc.gov.np \\
\hline PE & Public Enterprise & \\
\hline UN & United Nations & \\
\hline VAT & Value-Added Tax & \\
\hline VDC & Village Development Committee & \\
\hline
\end{tabular}




\section{INTRODUCTION ${ }^{1}$}

\section{This draft report provides an assessment of fiscal transparency practices in Nepal against the requirements of the IMF Code of Good Practices on Fiscal Transparency. The assessment has two parts. The first part is a description of practice, prepared by IMF staff on the basis of discussions with the authorities and their responses to the fiscal transparency questionnaire, and drawing on other available information. The second part is an IMF staff commentary on fiscal transparency in Nepal.}

\section{Description of Practice}

\section{A. Clarity of Roles and Responsibilities}

2. Roles of the executive, legislative, and judicial branches are clearly defined in the Interim Constitution. In January 2007 an Interim Constitution became effective that replaced the Constitution of $1990 .^{2}$ Executive power is vested in the Council of Ministers under the chairperson of the Prime Minister. The legislative branch is vested in a unicameral Parliament. A Public Accounts Committee of Parliament and an independent Auditor General (AG) are the institutions in charge of ensuring the integrity of information on fiscal policy.

3. The concept of general government is not used, although an increasing volume of expenditure is devolved to lower levels of government. The focus is exclusively on central government activities as defined in the budget, which does not cover all central government revenue and expenditure. ${ }^{3}$ Data collected for central government budgetary purposes is based on national practice, and does not fully accord with Government Finance Statistics (GFS)

\footnotetext{
${ }^{1}$ Discussions on fiscal transparency were held in Kathmandu from November 18 to December 2, 2004, followed up by further discussions held from May 16 to 29, 2007. The staff team in 2004 comprised Mr. Peter Kohnert (Head) (FAD), Mr. Renato Villela (FAD), and Mr. Arun Adarkar (expert, FAD); the staff team in 2007 comprised Mr. Peter Kohnert (Head) (FAD), Mr. Abdul Khan (FAD), Mr. Mario Pessoa (FAD), and Mr. Peter Harris (expert, LEG). The team met with the Secretary of the MOF, and with officials of the MOF (including from the Comptroller General Office, Budget and Program Division, Economic Analysis Division, Treasury Department, the Corporation Coordination Division, and the Inland Revenue Department), Ministry of Health (as a line Ministry), Ministry of Local Development, Office of the AG, Nepal Rastra Bank, Ministry of Physical Planning and Works, Commission for the Investigation of Abuse of Authority, Independent Tax Court, Office of Statistics, Federation of Nepalese Chambers of Commerce and Industry, Institute of Chartered Accountants of Nepal, World Bank, and the Asian Development Bank. Messrs. Sukhwinder Singh and Alexander Pitt (IMF Resident Representatives in 2004 and 2007, respectively) participated in some of the meetings and provided substantial support to the mission.

${ }^{2}$ Election to form a Constituent Assembly to draft a new constitution is planned. It is not clear so far if the Interim Constitution will be the basis for the new constitution. The term of the Constituent Assembly is two years and there is no provision limiting its scope.

${ }^{3}$ The terms "budget" and "Consolidated Fund" appear to be used synonymously by government officials but from a legal perspective this is not necessarily clear. There are some circumstances in which the Interim Constitution authorizes the use of resources from the Consolidated Fund without being included in the budget such as emergencies, natural disasters, and use of the Contingency Fund.
} 
classification. The local government level is comprised of 75 district development committees, 58 municipalities, and 3,913 village development committees. ${ }^{4}$ In addition, there are a number of social security institutions, but their data is not disclosed. There are a large number of extra-budgetary activities in the form of revolving funds ${ }^{5}$ under the supervision of line ministries, autonomous entities such as universities and colleges, and other public organizations.

\section{The allocation of responsibilities between different levels of government is} clearly defined but inter-governmental fiscal relations are not based on stable principles. The functions of the local government level are currently defined in detail in the Local Self-Government Act of 1999 and its regulations (see Box 1). The areas not defined as local activities in the Act are by default the responsibility of the central government. The financial relationship between the central and the local governments does not have a constitutional foundation, and the amount of transfers from the central to the local governments is determined each year in the context of the budget preparation. The Interim Constitution anticipates a restructuring of local government based on the principles of decentralization and devolution of power, but left for the Constituent Assembly to determine how and what is to be devolved.

\section{Government activities are sometimes carried out through public financial and} nonfinancial institutions and enterprises. Despite deregulation of prices in some areas, public enterprises - PE, public financial institutions, and the Nepal Rastra Bank (NRB, the central bank) pursue quasi-fiscal activities. There are no precise estimates of the amount of implicit subsidies, but they are significant. Prices of utilities and transportation are regulated and below cost, and interest rates on lending to agriculture and some industrial sectors are below market rates. For example, prices on petroleum products do not reflect changes in international prices, as a consequence Nepal Oil Company records substantial losses (about 1 percent of GDP) and arrears, leading to disruption in supply. While central government provides to PEs current subsidies and capital grants in the amount of about 0.3 percent of GDP, it does not compensate for losses incurred. In general, PEs have a low or negative rate of return on their capital due to price regulation, management problems, and over staffing. To address overstaffing, voluntary retirement schemes have been introduced in some PEs. A number of PEs are potentially not viable and have accumulated large contingent liabilities, including debt service arrears to the budget.

\footnotetext{
${ }^{4}$ Although the Central Bureau of Statistics, the Ministry of Local Development, and the National Rastra Bank collect and compile fiscal data on districts and municipalities, this data is neither used for general government consolidation nor published individually.

${ }^{5}$ Starting in FY 2003/04, some of these have been integrated into the budget (e.g., the Health Tax Fund).
} 


\section{Box 1. Local Government}

The Local Self-Government Act of 1999 distinguishes between institutions at the village level, the municipal level, and the district level. Functions delegated to the local level relate to agricultural development programs, drinking water projects, local infrastructure and maintenance, irrigation and conservation projects, basic education and health service issues, cultural affairs, development of tourism and cottage industries. For financing their budgets, local governments are permitted to levy taxes and charges such as land revenue and house tax, rent tax, enterprise tax, vehicle tax, property tax, entertainment tax, commercial video tax, advertisement tax, and parking and service charges. It is estimated that local governments raise 6 billion Rupees from own revenue resources. Furthermore, they receive current and capital grants from the central government budget which are not strictly based on a formula. In FY 2002/03 local governments received 0.6 percent of GDP in the form of operating subsidies and capital grants. The distribution of these transfers is partially based on indicators. In FY 2003/04 the central government transferred an amount of about 13 billion Rupees to local governments, either as conditional or as unconditional grants. Total unconditional grants to local governments have been in the range of 3 billion Rupees annually. Unconditional grants to Village Development Committees and municipalities are not based on any specific formula, while District Development Committees (DDCs) are awarded grants based on a formula with the following weighting: (a) population, 20 percent; (b) geographic area, 10 percent; (c) Human Development Index, 50 percent; and (d) price level, 20 percent. Conditional grants are tied to the approved program/project, such as education, health, etc. Since FY 2003/04, the government has introduced a performance grant scheme in 20 of the 75 districts under which districts fulfilling certain minimum conditions and achieving above 80 percent performance measures receive 25 percent additional grants. If performance is between 40 percent and 80 percent they receive capacity development and performance grants. DDCs with less than 40 percent achievement get only a capacity development grant. The Act also allows local governments to borrow money from banks and international organizations. The Local Self Government Act does not define any debt limit. The central government provides loan guarantees only in the case of foreign financed development projects.

\section{The NRB Act enables the central bank to have de facto independence from the} government. According to the provisions of the NRB Act, the Board of Directors is appointed by the Council of Ministers for five-year terms. The Governor, Deputy Governors, and Directors can only be dismissed, after due process, in well-defined circumstances. Although most of the interest rate subsidies are carried out through state-owned commercial banks, the NRB is still engaged in quasi-fiscal activities such as providing financial help to the Nepal Industrial Development Corporation and to industries in trouble through the "sick industry refinancing facility." The law restricts NRB lending to the government to short-term operations (up to six months) and payments related to the country's membership in international organizations. There has been some overdraft lending to the government in recent years. There are clear rules for allocating the Bank's net profits or net losses. ${ }^{6}$ The NRB does not pay interest on the cash balances in the government's accounts, nor charges the government for the services it renders as its fiscal and debt agent. The NRB also provides commercial banking services to PEs.

\footnotetext{
${ }^{6}$ After some deductions in favor of four different reserve funds, the remaining profit should be distributed to the government. Losses should be covered by the government after resorting to the reserve funds and to the Bank's capital (see Articles 41 and 42 of the NRB law).
} 


\section{Relations between the government and public financial institutions are for the} most part based on clear arrangements. Public and private financial institutions are guided by the same legislation, particularly by the Bank and Financial Institution Act 2006; Insolvency Act 2006; Secured Transaction Act 2006; and the Company Act 2006. A Money Laundering Control Act and Deposit and Guarantee Act are under discussion. There are a number of government-owned public financial institutions (apart from the central bank), including two commercial banks and four development banks. The oversight of these institutions is the responsibility of the NRB, but in practice the oversight is weak despite some penalties and efforts to set minimum performance criteria, and loan default is endemic. The commercial banks - the Rastriya Banjya Bank and the Nepal Bank Limited - both with large nonperforming assets, were declared technically insolvent in 2002. Similar problems persist at the two large development banks - the Agricultural Development Bank of Nepal and the Nepal Industrial Development Corporation - where the results of external audits suggest that large proportions of the loans of both banks are nonperforming. Financial sector reform efforts have recently begun to bear fruit, with better loan recovery and branch rationalization, although it has proved to be difficult to change the culture of nonrepayment of bank loans. There are government regulations requiring the banks' loan portfolios to include minimum percentages of lending to priority and deprived sectors. The regulations pertaining to priority sector lending are now being phased out. ${ }^{7}$

8. Government equity holdings are extensive and are published. At the end of FY 2006/07, 36 enterprises were under government ownership. PEs operate in six sectors. There are seven companies in the industrial sector, six in the trading sector, seven in the service sector, five in the social sector, three utilities, and eight public financial institutions. ${ }^{8}$ In 2006/07 these enterprises employed about 38,000 people. The largest employers are the Nepal Electricity Authority (10,320), Nepal Telecommunication Corporation $(6,260)$, and Rastriya Banijaya Bank $(3,599)^{9}$. Since 2002 , the central government regularly publishes annual data on the financial performance of state enterprises. Actual data is published with a one-year lag and only some state enterprises have completed audits, the number of these increased to 22 in 2006/07. Despite these improvements, final accounts are generally not completed in a reasonable timeframe. The report published by the Ministry of Finance (MOF) on PEs provides information on profit and loss, working capital and net worth as well as the number of employees and the status of final audit. ${ }^{10}$ The report does not analyze in each case what has caused the low rate of return or the loss, and does not make any reference to the impact of the government intervention (determining administrative prices) on their profitability. The $\mathrm{AG}^{11}$ only performs audit reports of PEs that are 100 percent publicly owned, and provides all reports to Parliament.

\footnotetext{
7 These regulations also apply to private financial institutions.

${ }^{8}$ The public financial institutions are six banks, one insurance company, and one stock exchange company.

${ }^{9}$ MOF appoints members to the Board of the PEs, but the accountability is weak.

${ }^{10}$ Report "Targets and Performances of Public Enterprises."

${ }^{11} \mathrm{AG}$ is member of INTOSAI and conducts the audits according to guidelines that follow the Nepal Standards on Auditing. AG's audit is guided by: Government Standards on Auditing, General Audit Guide, Procurement Audit Guide, Project Account Audit Guide, Revenue Audit Guide, Administrative Expenditures Audit Guide,
} 


\section{Procedures regarding privatization of PEs are well defined, but their} implementation has generated some complaints from the private sector. As per the privatization law, PEs can be sold according to the following modalities: sale of assets and business, sale of shares, and sale cum lease. In the former case, the enterprise is liquidated and its assets are sold. In the second case, the firm is not liquidated and its shares are auctioned. In the third case, the business is sold and the assets are leased for 10-35 years. ${ }^{12}$ The tendering process is carried out by the MOF and is publicly announced through the media. The announcements have to precede the selling date by 35 to 90 days. However, there appear to have been instances of the notice period being too short, and of potential buyers being hampered by the lack of proper accounts, including audited statements of physical assets. The AG has the responsibility of auditing the privatization process. The government has privatized 26 enterprises since 1992, of which three companies were privatized between 2004 and 2006. In December 2000, the government initiated its Build, Operate, and Transfer (BOT) policy aimed at attracting private capital into public infrastructure projects, but no actions have been taken to date.

\section{The clarity of government regulation of the private sector (see Box 2) has been} improved in some areas, but weaknesses remain. The Company Act of 1997 regulates accounting, financial reporting, and auditing of private sector organizations, but key concepts are not well defined and as a result there is a lack of clarity in terms of accounting standards and practices, and to a lesser extent auditing standards and practices. The Institute of Chartered Accountants of Nepal (ICAN) was created by the Chartered Accountants Act of 1997. However, due to a severe lack of human and financial resources many of its responsibilities are not completely fulfilled and its decisions do not reach the vast majority of accountants currently working in Nepal. The auditing function in comparison with the accounting is slightly better controlled. In terms of business environment, compared to the countries of South Asia, Nepal is rated by the World Bank as being close to the regional average in terms of corporate governance, judicial efficiency and costs in enforcing contracts, and in the time required to go through the bankruptcy process. ${ }^{13}$ The time required to register a business is the second lowest in the region, but the cost is the second highest and employment regulation is the least developed. Nepal also ranks poorly in relation to access to credit both in terms of the existing legislation on collaterals and bankruptcy and on the sharing of credit information.

\footnotetext{
and Directives to the Auditors of the Public Sector Enterprises.

12 The decision as to which modality applies to a given case is made by the Privatization Committee, created by law to coordinate the process.

${ }^{13}$ The World Bank, Nepal: Doing Business in 2007. Comparison with India, Pakistan, Sri Lanka, Bhutan, and Bangladesh.
} 


\section{Box 2. Government Regulation of the Private Sector}

The government's regulatory functions are carried out through a number of different agencies. In the banking sector, governance aspects are monitored by the Registrar of Companies, while operational aspects are supervised by the Nepal Rastra Bank (the central bank). The Registrar of Companies also monitors governance aspects in respect of all registered companies. These companies are required to have their accounts compiled and audited according to internationally accepted accounting standards. Similarly, company secretaries are required to be duly qualified.

Large companies in certain sectors are sometimes governed by specific legislation. All companies in the petroleum sector, for example, will soon be governed by the Petroleum Act, which is currently under enactment.

Regulatory agencies have also been established for certain sub sectors and activities. Examples are the Environment Protection Council, Civil Aviation Authority, Insurance Committee, Nepal Standards and Metrology Department, Accounting Standards Board, Auditing Standards Board, Drug Management Department, and the University Grants Commission.

11. The legal base and regulation for taxation are in place and are generally clear. ${ }^{\mathbf{1 4}}$ The government has introduced measures to improve public understanding of the tax and customs systems. The Inland Revenue Department (IRD) and the customs administration publish printed materials to inform and help train smaller tax payers and importers/exporters. The IRD and customs also publish on their websites ${ }^{15}$ the regulations and guidelines concerning tax and customs administration. Toll-free calling has been introduced and an SMS messaging service will be implemented shortly. The IRD is making good progress in establishing a modern and effective Large Taxpayer Office (LTO), which communicates with the approximately 220 large taxpayers, although further work is needed to improve operational performance, particularly in audit.

\section{In spite of recent improvements, some weaknesses remain in the revenue}

administration. Although both tax and customs administrations are autonomous in their dayto-day activities, there is no legislation specifically protecting the staff of these administrations from political interference in the conduct of their duties, for example, establishing tax liabilities of individual taxpayers or selecting taxpayers for audit. The LTO has a staff performance incentive scheme that pays an additional proportion of base salary for revenue collections from audits which exceeds targets. A similar scheme has been on trial in one customs office for about 6 months. ${ }^{16}$ These schemes are funded from departmental budget allocations, and not from revenues. Additional revenues resulting from income tax, VAT, and excise audits are credited to the Consolidated Fund and are not used for performance incentives or to defray administrative expenses. ${ }^{17}$ Excise administration in the

\footnotetext{
${ }^{14}$ Government revenues amount to about 13 percent of GDP, of which tax revenue accounts for $101 / 2$ percent of GDP and nontax revenue (e.g., passport fees, etc.) 21/2 percent of GDP.

${ }^{15}$ www.ird.gov.np and www.customs.gov.np.

16 The operation of the customs scheme was reviewed by an FAD expert in June 2007.

${ }^{17}$ However, a proportion of the proceeds from sale of smuggled goods confiscated by customs or the revenue investigation department is used for monetary incentives to persons who have provided tips or information about the smuggling to the authorities.
} 
IRD remains weak and the MOF has serious concerns about excise revenue leakage and evasion. In customs, administration of tax exemptions on imports is weak, and the Ministry has similar concerns about revenue loss. Stakeholders are concerned at customs' inability to counter reportedly large-scale smuggling. The internal audit systems in IRD and customs are basic, the focus is on financial flows, and performance is not audited. ${ }^{18}$

13. Although improving, taxpayers' attitudes towards the IRD remain somewhat negative and the level of compliance remains below the degree hoped for by policy makers. Taxpayers are aggrieved by the compulsory nature of recent changes ${ }^{19}$ and the compliance level for these measures is still low. There is a certain reluctance of some staff to adopt new procedures, a low integrity level among staff (although some measures have been introduced to deal with this issue $\mathrm{e}^{20}$ ), and the absence of capacity to deal with human resource management issues. Furthermore, there are outmoded processes in excise control procedures and in key areas of income tax such as dispute resolution, refund management, and audit.

14. In the customs administration, important operational procedures are outmoded and technical capacity is low despite recent training in valuation, audit, and risk management. Import and export clearance procedures are inefficient, and poorly supported by the existing computer system. The ability to administer the valuation law and to audit the declarations of importers remains limited. There is an undesirable level of interaction between officials and clearance agents, leading to integrity concerns and a lower than desirable level of compliance. Improved procedures are being introduced under trial at one customs site and if successful will be implemented more widely. Customs is to address these issues in its three-year reform plan, but has limited capacity for improvement without technical support. A project under the reform plan to upgrade and extend the computer system, which has been stalled for some years, is now expected to mobilize shortly. This will allow the introduction of more efficient clearance procedures and enable interactions between customs agents and customs staff to be reduced.

\section{The legal and administrative framework to define roles and responsibilities for} fiscal management is fairly detailed, but fragmented. Part 9 of the Interim Constitution provides detailed provisions on financial procedures for the Consolidated Fund and for other government funds such as the revolving funds. Public funds can only be spent by law, budget transactions have to be recorded in gross terms, and independent audit reports are required. Furthermore, the role of the different institutions in the budget process at the central level is laid out in the Financial Procedures Act of 1999 and its regulations. The right to create extrabudgetary funds is stipulated in the Revolving Fund Act. Funds are also instituted under the Administrative Procedures Act or under their own acts. Financial procedures related to extrabudgetary funds are codified in various acts such as the Revolving Fund Act, the Road Board

\footnotetext{
18 The authorities indicated that both tax and customs departments have implemented a system of monthly and annual performance indicators to monitor the performance of respective offices.

${ }^{19}$ Including electronic income tax deduction at source (ETDS) and requirements for traders issuing tax receipts to use approved printers and cash registers.

${ }^{20}$ The authorities indicated that this issue has been addressed by introducing taxpayer self assessment and reducing personal interactions between taxpayer and officials.
} 
Fund Act, the Peace Fund Act, and the Judiciary Revolving Fund Act. However, the Acts do not require transparency in the operation and reporting of individual funds. These funds are meant to provide flexibility to raise and utilize additional resources without the constraints of the budgetary process. A number of these funds also receive transfers from the Consolidated Fund and certain earmarked tax revenues.

16. There is no coordination of extra-budgetary activities with the budget although such activities receive transfers and/or a direct diversion of certain taxes. ${ }^{21}$ Extrabudgetary activities are also not subject to the government's accounting procedures, but most of them are audited by the AG. Because the minister of a line ministry is usually the chairman of a committee that administers the respective fund, some consistency with government policy may be ensured. In the case of the Army Welfare Fund (AWF), revenues from the UN for the service of Nepali military personnel are not channeled through the budget, but are directly deposited with the AWF. The accounts of the AWF are neither published nor open to public scrutiny in any way. Since the AWF is outside the Consolidated Fund, the Financial Comptroller General's Office does not have any direct oversight. The Nepali Police force has a similar fund, the Police Welfare Fund, created with proceeds from the rent of government property.

17. There are problems in coordinating donor activities. Aid comes in the form of financial and nonfinancial aid and this aid does not always enter the government accounts and budget. In some cases, the Nepali Government provides the manpower needed to carry out projects while donors provide commodity aid. Frequently, both activities are not well coordinated with the result that the appropriated funds are disbursed, but the intended output is not achieved. To alleviate these problems, some donors have agreed to provide their aid component in cash to the government's budget while others still insist on disbursing their aid outside the budget. Nevertheless, the Fiscal Procedure Act (FPA) stipulates clearly that all assistance in cash or in kind, including from international organizations, shall be part of the Appropriation Act.

\section{An attempt has been made to improve budget classification of expenditures in} FY 2004/05 by introducing a new chart of accounts (COA). However, the new COA also has some serious deficiencies. First, the COA is not suitable for double entry accounting because it does not contain necessary bank and cash accounts. Second, the COA is incomplete because it misses accounts to record proceeds from issuance of debt. Third, the COA treats financing items such as debt and lending, as revenue and expenditure.

19. The legal framework demands achievement related budgeting. The government has developed in a number of sectors strategies, objectives and indicators that allow a performance based budgeting and execution process. The release of funds for development projects is formally linked to progress in the physical implementation of the project.

However, as the necessary physical verification cannot take place in most cases due to lack of competent staff and timely information, the release of funds is based mainly on written

\footnotetext{
${ }^{21}$ For example, the Tourism Board directly receives the Tourism Development Fee collected by Revenue Offices.
} 
statements of the executing agency or ministry. Therefore, in practice, the main focus is on financial compliance with use of the appropriated funds.

20. Public servants are subject to a code of behavior. The body of public servants comprises about 88,000 civil servants working in line ministries and their subsidiary units, and other employees working in public entities such as the Nepal Rastra Bank and PEs. All civil servants are governed by the Civil Service Act and by regulations framed under the Act. These regulations include a code of behavior and infractions are punishable with a wide spectrum of disciplinary actions, ranging from a warning or a temporary stoppage of the annual increment in the pay scale to dismissal. Public entities and PEs have similar codes of behavior for their respective staffs. Certain requirements, however, apply to all public servants, the most prominent example being the requirement to declare annually all property and financial assets. ${ }^{22}$ Also, in respect of all public servants, cases of suspected corruption may be referred to the Commission for the Investigation of Abuse of Authority (see Box 3).

\section{Box 3. Anticorruption Measures}

The Commission for the Investigation of Abuse of Authority (CIAA) is an autonomous, financially independent constitutional body. Established in 1990, it is the only institution mandated to prosecute cases of corruption in public life. The Anticorruption Act of 2002 gives powers to the CIAA to seize goods and documents, and issue warrants for arrest and detention. The CIAA is also empowered to involve the police and other government authorities in its investigations.

According to its latest Annual Report, the CIAA received 4,759 new complaints in FY 2005/06 and filed 98 cases. As of the end of FY 2006/07, a cumulative number of 680 cases have been filed by the CIAA with the specially constituted court to hear such cases. Of these cases 460 have been decided, with 85 percent of the decisions in favor of the CIAA. However, all of these decided cases have been appealed to the Supreme Court, which is yet to make a single decision on appeal.

Charges of corruption against Judges of the Court of Appeals and the District Courts are investigated by the Judicial Council, a statutory body established in 1990. The Judicial Council is headed by the Chief Justice of the Supreme Court and comprises the Minister of Law and three judges of the Supreme Court as members. Charges against military personnel are handled in accordance with special military regulations.

\footnotetext{
${ }^{22}$ Since 2003, this requirement has been applied even to staff of commercial enterprises in which the government has a minority holding. While staff seems to comply, it is not clear if the information is used in practice to assess the consistency between earnings and increase in wealth.
} 


\section{B. Public Availability of Information}

21. A large amount of information is published and is also made available on
websites, but important information about budget execution are not available. However, these publications are printed in small numbers, presumably because of budgetary constraints, and are therefore not always available to interested parties in this form. Some important information, such as the impact of contingent liabilities, quasi-fiscal activities, and other complementary budget information are neither produced nor published.

\section{While publication of fiscal information is not a legal obligation of the} government, there is public commitment to publish fiscal information. The MOF releases in the FCGO's website quarterly information on budget execution. However, there are no advance release calendars for fiscal reporting to the public although Nepal subscribes to GDDS since 2001.

\section{Information on fiscal activities is confined to the central government's budget.}

The budget documents do not contain information on any other general government component or on extra-budgetary funds. These documents include information on revenue and expenditure in summary tables, as well as a breakdown by ministry with a distinction between recurrent and capital expenditure and an indication of prioritized expenditures by sector. Data is also presented in an economic and administrative classification, and in a particular classification defined as regular and development. In the wake of privatization of enterprises, the budget document, starting FY 2003/04, contains provisions for the clearance of utility arrears and liabilities of those PEs which are to be liquidated or divested. The budget document also identifies the amounts expected to be raised by additional revenue measures, and the relevant measures are discussed. Although the budget speech refers to new expenditure programs, the budget itself does not separate expenditures for new programs and policies from existing ones. Likewise, the budget documentation contains information about the two previous years, but no analysis or review of the preceding year's budget implementation is made in the budget speech nor is there any comparison between the budgeted and actual numbers.

\section{A medium-term expenditure framework (MTEF) is prepared but it is not} available to the Parliament before the budget is approved. MTEF $^{24}$ contains detailed information about capital expenditure and sectoral development strategies, while suffering from the same deficiencies as the budget with regard to insufficient coverage and lack of information on quasi-fiscal activities, other contingent liabilities, and macroeconomic sustainability. The preparation of the MTEF and the annual budget are still not fully

\footnotetext{
${ }^{23}$ Latest available publications: Public Statement of Income and Expenditure of FY2006/07 (budget speech); Consolidated Financial Statements of the Government/Nepal FY 2005/06 (annual accounts by the Office of the Financial Comptroller General); Medium-Term Expenditure Framework FY 2003/04-2005/06 (by the National Planning Commission); Economic Survey FY2004/05; Economic Report of the Nepal Rastra Bank 2002/03; Quarterly Economic Bulletin of the Nepal Rastra Bank (Oct 2003/Jan 2004); Targets and Performances of Public Enterprises FY 2006/07; Annual Report of the Auditor General 2006.

${ }^{24}$ In addition, the Government in 2002 published its tenth ten-year plan that for the first time included goals related to the poverty reduction strategy and the millennium development goals. This long-term plan is revised annually and the appraisal influences the preparation of the medium-term expenditure framework.
} 
integrated, with the MTEF being the Planning Commission's responsibility and the budget being the MOF's. As the MTEF is published after the budget has been approved, the Parliament does not have an opportunity to examine and assess the macroeconomic assumptions used to prepare it. In fact, the budget is presented to the Parliament in the last month of the fiscal year, giving almost no time for an appropriate discussion.

25. There is no comprehensive information on contingent liabilities in any budget document published by the government. The government incurs a number of contingent liabilities through its guarantees to trust funds like the Employees Provident Fund and the Poverty Alleviation Fund, and through its guarantees, implicit and explicit, to PEs. According to the 2006 report on PEs, the MOF has estimated that at the beginning of fiscal year 2005/06 contingent liabilities of PEs amounted to 10.3 billion Rupees (2 percent of GDP). The budget contains no provisions for these or other contingencies.

26. Tax expenditures are not estimated. The authorities claim that there are no major tax expenditures in Nepal, and that only some small reductions on tax rates apply for taxpayers in remote places. However, most agricultural income is exempt from taxation and the income tax law contains other concessions for special industries. In particular, implementation of the Special Economic Zones Act will reintroduce tax holidays that are already provided for in the income tax law. The minimal taxation of certain employee benefits (cars and housing) also amounts to tax expenditure. Estimates on the impact of new tax measures on tax collection are made by IRD and customs, but only for internal use.

27. Quasi-fiscal activities are not estimated, but they are significant. These activities are extensively carried out both by financial and nonfinancial PEs. The most prominent examples are the price subsidies to fuel, electric energy, and interest rate subsidies for agriculture and other priority economic sectors.

28. Some defense expenditures are reported in the budget with the same detail as for other ministries, but substantial amounts remain outside the budget. Externally funded defense expenditures are usually not included in the budget and the amounts are unknown. Substantial amounts of resources are deposited in the extra-budgetary Army Welfare Fund (AWF). The bulk of these latter resources come from the United Nation (UN) as repayment for the participation of the Nepali armed forces in peace-keeping activities abroad. Even though these services are primarily supported with budget funds, the reimbursement is directed to the AWF.

29. Information on gross public debt is published as part of the annual Consolidated Financial Statements. Separate tables for domestic and foreign borrowings include for each loan the payments of principal and of interest, and outstanding balance. However, no information is published on the government's financial assets.

\section{The classification of fiscal information is not consistent with international}

practice. The economic classification does not comply with the GFSM 2001, although revenue and expenditure components can be related to GFS categories. There are differences in the breakdown of revenues and the composition of expenditures. Repayment of debt is classified as expenditure. Expenditure on repairs and maintenance and new capital 
expenditure are classified together. ${ }^{25}$ The functional classification used is not in accordance with the UN Classification of Functions of Government (COFOG).

\section{Open Budget Preparation, Execution, and Reporting}

\section{Broad objectives of fiscal policy have been recently included in the budget} speech but the sustainability of fiscal policy over the longer term is not examined. There is no disclosure of the basis of revenue forecasts (and their underlying assumptions), risks (e.g., realization of contingent liabilities, impact of exchange rate fluctuations on debt servicing), and mitigating measures and provisions.

32. The government is not bound by formal fiscal rules except by overall monetary financing by the central bank (overdraft) limited to 10 percent of previous year's total revenue. There are no fiscal rules specified or adopted such as a balanced budget requirement or general borrowing limits. ${ }^{26}$ The MTEF does not contain any guidance related to fiscal rules. However, the government makes a de facto attempt to contain recurrent expenditures within projected revenues.

\section{The introduction of an MTEF in 2002 in line with the long-term plan was an} important measure to improve the medium-term outlook of the fiscal policy. The preparation of a long-term plan, the MTEF, the budget proposal and the budget speech provides a broad economic background and indicates some assumptions, economic growth and inflation rate underlying the estimates, including fiscal and other social and economic indicators for the coming three years. These indicators are presented in a tabular form to facilitate analysis. However, some indicators do not seem to be consistent with actual economic situation. For example, the GDP growth projected by the MTEF for 2007/08 is 6 percent, but according to IMF projections it is expected to be $4 \frac{1}{2}$ percent. $^{27}$ The use of inadequate assumptions in this context can undermine budget realism and impose difficulties in fiscal management. Revenue and expenditure projections are based on past trends and augmented by amounts calculated from revenue raising measures. The annual budget contains investment projects that were scrutinized and prioritized by the National Planning Commission in cooperation with line ministries and the MOF.

34. There is a budget calendar and it is published. The Budget Formulation Manual, prepared in accordance with the Financial Administration Regulations, ${ }^{28}$ has been printed and circulated to all government agencies. It is also available to the public in Nepali on the Finance Ministry's website at http://www.mof.gov.np. However, there are no legal provisions governing the budget calendar and so it could be changed from year to year.

\footnotetext{
${ }^{25}$ The application of a chart of accounts on the basis of GFS 2001 does not necessarily imply the introduction of accrual accounting, but can be used within the limitations of a cash accounting system.

${ }^{26}$ Annually, the Public Borrowing Act sets a domestic borrowing ceiling and the Loan and Guarantee Act sets the maximum stock of the foreign debt the government can hold in a year.

${ }^{27}$ Second and Third Reviews Under the Three-Year Arrangement Under Poverty Reduction and Growth Facility, October 2006.

${ }^{28}$ The Financial Administration Regulations, Section 20(i) empowers the MOF to develop budget preparation guidelines, which also include a timetable, binding for all other ministries.
} 
35. The budget speech highlights new policy initiatives, but they cannot be identified in the attached tables on budget estimates. It is also not possible to identify, either from the budget speech or from the data attached, the results of the policy initiatives of the previous year. Furthermore, the budget is not transparent in regard to revenues diverted to extra-budgetary funds.

36. The overall deficit of the central government's budget is the main focus of fiscal policy. It is used in the MTEF and mentioned in the Budget Speech. No other analytical indicators are used.

37. Public reporting in relation to performance of the programs during budget implementation is weak. A basic weakness stems from the absence of a linkage of expenditures to specified goals, and from the fact that budget codes do not reflect activities. Despite the existence of an elaborate system of committees at various levels to monitor expenditures, no detailed information is published during the year on budget implementation, apart from the financial quarterly report and the mid-term budget evaluation report published by the MOF since FY 2002/03. The mid-term evaluation examines progress towards new policies and programs identified in the budget speech, and it also examines the progress of select high priority programs/projects. However, there is no review of the success of major budget programs in achieving their announced objectives, nor are the results achieved in relation to the objectives of such programs published.

38. Performance reviews do not indicate whether intended results have been achieved. Article 93 of the Interim Constitution requires that the annual budget estimates of revenue and expenditure be accompanied by a statement from each ministry as to whether the objectives of the expenses allocated in the previous year have been achieved. In practice, the reports on performance from the ministries and departments accompanying their budget submissions to the MOF indicate not only the actual amount of funds expended against the allocation, but also some information about performance. Performance auditing is undertaken to a limited extent, both in terms of contents and coverage, by the AG.

39. A mid-term review is undertaken and aggregate figures are released to the press.

The government undertakes a review of overall economic development and revises the estimates of revenue and expenditure. However, supplementary budgets are rarely resorted to; unanticipated shortfalls are met by domestic borrowing. There is no effective constraint to borrowing other than a letter of agreement between the MOF and the central bank.

40. Internal control procedures are not fully effective, and the accounting system needs to be substantially strengthened. Disbursements are made by District Treasury Officers, through local banks or branches of the NRB, on the basis of payment orders authorized by officials of the line ministries and other budgetary units. These disbursements are reported monthly by District Treasury Officers to the Financial Comptroller General's Office. The field offices also send to their respective headquarters monthly expenditure statements. There is no provision in the system to control, ex ante, expenditure commitments by field offices or budgetary units. There is therefore no way of identifying arrears at any given time, or of highlighting a developing arrears problem, as the accounts are maintained wholly on a cash basis. Since FY 2002/03 the Financial Comptroller General's Office has 
been preparing an annual statement of all expenditure arrears. The process is being refined every year but still needs substantial improvement. Under the present system, only permissible arrears are reported, while many spending agencies incur expenditures for which accruals are not permitted by law and hence do not get reported through the Treasury Offices. Also, commitments, referred to by Nepali officials as encumbrances, are wholly outside the reporting system. Revenue arrears are reconciled and reported.

41. The procurement and contracting procedures are clear and well defined. These are currently contained within a larger body of rules, the Financial Administration Regulations. A new Procurement Act is being prepared with World Bank assistance and in consultation with multilateral donor agencies. It is close to finalization and expected to become law in 2007. This Act will specify detailed procurement procedures and various financial thresholds (e.g., for international competitive bidding, international shopping, direct purchase, etc.) in accordance with international standards. It will govern all procurement of goods and services by the government and government entities, whether financed by domestic or external resources. Bilateral donor agencies securing goods and services in their own countries for their aid projects in Nepal will continue to apply their own procurement rules.

42. The internal audit of public procurement is patchy and weak. Inspection of goods supplied or works executed under contracts is often carried out by junior level nontechnical staff of the District Treasury Office and occasionally by technical staff from headquarters. This inspection is both on a sample basis and after the corresponding payments have been made. There is no systematic and effective follow-up in terms of imposing financial penalties on or withholding earnest moneys from contractors or suppliers failing to meet contracted specifications. A National Vigilance Centre (NVC) was established in 2002 under the Prime Minister's Office to receive complaints from members of the public, and a Technical Audit Section in the NVC is being set up with assistance from the Asian Development Bank. The NVC, however, has no investigative capacity, and cases that prima facie involve corruption or abuse of authority are referred to the Commission for the Investigation of Abuse of Authority. An annual report is published by the NVC.

43. The Internal Revenue Department and the Customs Administration are not given legal protection from political interference. Both tax and customs administrations are subordinated to the Revenue Department of the MOF. The key positions in both departments are filled at the discretion of the Ministry. There is no law defining special procedures for appointment to these positions, nor terms for the officials.

44. There is no legally prescribed time limit for publication of the audited financial statements. Each year the AG determines a timetable for submitting various reports and for issuing his own report. Generally, ministries are required to submit their accounts to the AG within three months of the close of the fiscal year and the Financial Comptroller General (responsible for maintaining the government's accounts) is required to submit the consolidated financial statements within six months. Over the past few years the audited financial statements of the government have been issued about 13 months after the close of the fiscal year. 


\section{Independent Assurances of Integrity}

45. Budget data is not realistic, and the variance with actual budget data is high. In general, revenues and expenditure are overstated in the budget compared to the actual outcome. ${ }^{29}$ In recent years, the budget deficit has also tended to be overestimated.

46. External scrutiny of macroeconomic models and assumptions is not made. There is no discussion with universities or think-tanks on the macroeconomic framework of the budget. (4.2.2)

\section{The published financial statements of the government include statements of} accounting policy. The basis of accounting is provided in the final financial statements. The accounting is wholly on a cash basis, and accrued expenses from a previous year are shown as expenditures in the year in which they are paid. The final financial statements are published by the MOF within seven months of the close of the financial year and one month after submitting them to the $\mathrm{AG}^{30}$ These are also made available on the Financial Comptroller General's website. ${ }^{31}$ However, these financial statements essentially pertain only to the Consolidated Fund, to which budgeted receipts and expenditures are credited and charged, respectively. ${ }^{32}$ The financial statements do not contain the accounts of a significant number of extra-budgetary funds and activities, nor are the receipts of such funds credited to the Consolidated Fund. The financial statements also do not fully include all foreign aid components (e.g., direct payments and commodity grants) as they do not pass through the accounting system. The statements include a tabular comparison of total expenditure against the budget provision for each budgetary unit such as line ministries and units for which the expenditure is budgeted, but is not subject to parliamentary vote (e.g., expenditure of the AG, Parliament, and CIAA, repayments of foreign loans, etc.,- - total of 12 such heads). Virements are shown separately in the same table. Expenditures by line item are shown for each budgetary unit on the basis of economic classification consistent with the budget.

\section{A statement on data reconciliation is included in the annual Consolidated}

Financial Statements. The expenditure figures obtained from two sources - the District Treasury and Control Offices (DTCO) and the line ministries - are reconciled by the Financial Comptroller General's Office. In the event that a figure cannot be reconciled, the figure reported by the DTCO is used.

49. The AG has complete and unfettered independence. The AG's tenure, powers and professional independence are laid down in the Interim Constitution, and the AG's budget is charged directly to the consolidated fund and is not subject to the annual appropriation

\footnotetext{
${ }^{29}$ For example in FY2005/06, foreign grants and capital spending were overestimated by about 30 percent, foreign loans by more than 75 percent.

${ }^{30}$ The financial year ends mid-July.

${ }^{31}$ http://fcgo.gov.np

32 The Financial Comptroller General (head of treasury) does not maintain records on commitments or liabilities (including arrears).
} 
process. ${ }^{33}$ However, the budget of the office is routed through the MOF, which is therefore able to restrict the AG's staffing demands. The AG has full access to all documents related to the accounts of the government and PEs, except in the cases the PE is not fully owned by the government. In this last situation, the $A G$ is required by law to recommend a firm of chartered accountants as the auditor of PEs that are not wholly owned by government (more than 50 percent and less than 100 percent).

50. The AG's audit is not conducted fully in accordance with international standards. For example, the AG does not provide an audit opinion on the consolidated financial statements of the government. The audit standards are based broadly on those of the International Organization of Supreme Audit Institutions and on the International Standards on Auditing issued by the International Federation of Accountants. However, despite the large number of audit documents published the AG does not highlight systemic issues or provide recommendations on the manner in which they can be addressed. The standards and guidelines of the AG's are updated from time to time in light of changes in various international rules and regulations. To ensure observance of these standards and guidelines, there is an internal quality review process under which one unit reviews the work of another.

51. The coverage of audit is broad. The scope of the AG's audit includes not only all revenues and expenditures pertaining to the Consolidated Fund, but also the accounts of all extra-budgetary funds which receive government funding and of PEs wholly owned by the government. As noted above, the AG does not audit partially owned PEs. The AG's functions have been substantially broadened in recent years by the introduction of the performance audit of large projects, mainly financed by donors. The government also seeks the advice of the AG on a number of financial and accounting issues as they arise.

52. There is a formal system in place to follow-up on the AG's recommendations; however, in practice, this system is yet to be proven to be effective. With the adoption of the Interim Constitution of 2007 the Public Accounts Committee has resumed its functions and audit issues have been discussed. According to the Interim Constitution, the AG has to submit to the Prime Minister an annual report on work performed, and the Prime Minister has to submit the report to the Parliament. The AG, on his own initiative, brings the major financial irregularities detected in his audit to the attention of the concerned ministry. However, he does not have the authority to ensure that appropriate action is taken on the reported irregularities. While action may indeed be taken in certain cases, in the absence of an effective system for follow-up and reporting, there can be no assurance that all the financial irregularities reported by the $\mathrm{AG}$ have been, or will be, rectified and remedial action taken to prevent their recurrence.

\section{The Central Bureau of Statistics (CBS) has legislative assurance of} independence, but has been unable to institutionalize a modern statistical system. The Statistics Act explicitly guarantees the independence of the Bureau. Its autonomy is also reinforced by the fact that it is organizationally linked to the National Planning Commission, and not to any ministry. But the CBS is not able to coordinate the collection and production

\footnotetext{
${ }^{33}$ Interim Constitution Article 92 and Part 12.
} 
of statistics. A Consolidated National Statistical Plan was formulated in an effort to address the coordination issue. Under this plan decision making is exercised by the National Statistical Council.

\section{IMF STAFF COMMENTARY}

54. The government has made a number of laudable efforts to increase transparency and accountability in recent years. It has created the CIAA and the National Vigilance Centre (NVC) to enforce accountability of politicians and the bureaucracy; published guidance material for taxpayers and organized public hearings in the tax and customs administrations; and reclassified expenditures into recurrent and capital to increase transparency and has discontinued the practice of preparing separate recurrent and development budgets. Furthermore, it has implemented a simplified version of a MTEF, documented it well, and published the results of a mid-term review of the budget. The publication of the financial performance of state enterprises is also evidence of the government's commitment to improve transparency. The Annual Report of the AG is available to the public. It is critical that this momentum is used by the government to implement steps for a systematic approach to achieve international standards of fiscal transparency. Transparency is an important ingredient for good governance, macroeconomic stability and high-quality growth. It makes those responsible for the design and implementation of fiscal policies more accountable for their activities.

55. Further transparency measures have been announced by the government. The Finance Minister's announcement in his 2006/07 budget speech of the government's intention to enact a Transparency Act during this fiscal year is an important step in the right direction. As transparency and accountability require a systematic approach and should meet international standards, this new Act should reflect the standards and codes of fiscal transparency, e.g., those defined by the IMF and which are used as benchmarks in this report. The Finance Minister also expressed his intention to provide periodic accounts of budget execution and of the physical progress in project implementation. Staff stress the importance of a swift realization of these announcements. The government is also actively pursuing a number of public sector reforms with the support of the donor community. ${ }^{34}$

56. More effective enforcement of the laws, rules and regulations is necessary for the operation of a more transparent financial system. Nepal has by and large a good legal framework and a large number of rules and regulations all of which, if enforced, would result in a significant improvement in the transparency and accountability of public financial management. Law enforcement assists in making fiscal policy more effective. It is also essential for ending various anti-social practices such as the culture of well-connected borrowers not repaying bank loans and the depletion of the capital of PEs. ${ }^{35}$

\footnotetext{
${ }^{34}$ For example, improvement in external audit and introduction of a new procurement act.

35 "As willful defaulters pose a serious threat to the health of the entire banking system, they are enemies of the nation."-Deputy Prime Minister and Finance Minister Bharat Mohan Adhikari (The Kathmandu Post, November 19, 2004).
} 


\section{Revenue administration}

57. The government's efforts to improve revenue administration should be supplemented by modernizing personnel management. This requires firm, transparent and significant action in a number of areas. Mechanisms should be implemented to improve the integrity of staff, the management of recruitment, career development and training, and discipline, accountability, and performance management. There is also a need to refocus human resources towards more productive activities, e.g., away from traditional assessment and into strategic audit and cross-checking.

\section{The government should intensify its efforts to strengthen tax and customs} administration. In some instances, notably excise and tax and customs duty exemptions, it will also be necessary to review and simplify policies that are complex and difficult to administer. Urgent attention is necessary to improve large taxpayer and VAT audits, income tax dispute resolution, and management of refunds. Efforts should be made to identify and take recovery action against the VAT taxpayers whose registration has been suspended but who continue to trade outside the VAT system. In customs, every effort should be made to mobilize the computerization project and continue to build technical capacity in valuation, audit, and risk management.

\section{Budget coverage}

\section{The coverage of the budget should be widened in line with international} standards. The focus of the central government budget is too narrow and does not cover comprehensively all central government activities. It is crucial for transparency and accountability with respect to the government's actions that the budget includes all revenues and expenditures of the central government. Good practice is to include the following activities in the budget:

- The revolving funds: the government should review whether there is any good reason to keep revolving funds outside the budget. At a minimum, these funds should be subject to the same rules and regulations as the revenues and expenditures of the Consolidated Fund. Further, the mandate of the Financial Comptroller General should be widened to integrate the accounting of these funds' operations into the main system. Budgets relating to the revolving funds and information about their execution should be included in the budget documents and a truly Consolidated Central Government Budget presented.

- Autonomous entities: the boards and other organizations (including universities, colleges, and some hospitals) that are created and controlled by the central government and considered autonomous agencies should be included in the budget or at least in the budget documentation.

- $\quad$ The Army Welfare Fund: the income of this fund (receipts from the UN) should be credited to the Consolidated Fund and accounted for in the budget. Expenditures financed from these revenues should also be disclosed. 
- Similar considerations apply to the Police Welfare Fund.

In the event that there are insurmountable difficulties to including these items in the budget, they should, at the very least, be disclosed in the budget documents. A consolidated budget incorporating all budgetary and extra-budgetary activities should also be prepared and included in the budget documents.

60. The government should present information about all other general government activities. The general government sector (as defined in the GFSM 2001) consists of all central and local government units and all nonprofit institutions that are controlled and mainly financed by the government. ${ }^{36}$ The concept of general government incorporates all nonmarket activities of government and so is important in comprehensively assessing national fiscal policy and its impact on macroeconomic development. This means the budgets of all general government units should be included in the budget documentation and consolidated in a Consolidated General Government Budget. To achieve this, the government needs to make reporting mandatory for all general government units and define the standards, periodicity, and timing of reporting.

\section{Budget preparation and execution}

\section{The published budget documentation should contain more analytical}

information necessary for good financial management. The current budget presentation of fiscal data is not accompanied by underlying macroeconomic assumptions, evaluation of risks, and other explanations. Therefore, the presentation is not suitable for public analysis and policy accountability. Some of the information needed is already available in the system. As a start, the following should be included with next year's budget presentation:

- $\quad$ Basic macroeconomic assumptions and indicators: a macroeconomic framework has been developed under the Poverty and Growth Reduction Facility.

- $\quad$ Contingent liabilities: they arise from government guarantees and other arrangements that could imply a future liability of the government. Contingent liabilities also include the eventual costs that the budget may have to carry as a result of poor financial performance of PEs. Similarly, costs can also arise from nonperforming loans held by financial institutions that have been financed by the government borrowing from international banks. These potential risks for the budget should be disclosed in an annex to the budget document. Contingent liabilities may also arise from public-private-partnership (PPP) arrangements such as build-operate-buy (BOT). Best practice is to estimate the likelihood of the event occurring and make an appropriate provision.

- A statement on tax expenditures: tax expenditures are forgone revenues as a result of concessions for certain specific activities such as the exemption of large parts of the agricultural sector from income tax. A statement of these foregone revenues would disclose the cost of such arrangements. After preparation this information should be

\footnotetext{
${ }^{36}$ Common examples are hospitals, universities, and other public institutions.
} 
included as an annex to the budget documents. This would facilitate public analysis of the amount and the intended objective of such concessions.

- An estimation of quasi-fiscal activities: these include concessional interest rates granted to target groups, sectors and regions and any type of price regulation that deviates from market pricing (e.g. that of utilities, petroleum products, etc.).

- A statement on risks should be compiled to indicate the possible impact on the overall fiscal position of changes in key assumptions or contingent events, together with mitigating measures.

- A distinction between ongoing and new initiatives.

- Information on future commitments under multi-year projects and contracts.

- A systematic review of the implementation of initiatives announced in the previous year's budget speech, including reference to declared objectives and their achievement measured by relevant output and outcome indicators.

\section{The MTEF can be further developed to strengthen assurance of policy}

accountability. The MTEF is a good instrument for presenting policy intentions and achievements in a larger context. It can take a long time after establishing such a system for it to be fully effective in assisting policy design. The MTEF should use realistic macroeconomic indicators, distinguish between new and ongoing projects and be expanded to analyze:

- The sustainability of current macroeconomic and sectoral policies.

- $\quad$ The trend of recurrent expenditures.

- The debt sustainability.

- $\quad$ Success and failure in program implementation.

- $\quad$ Consequences for resource allocation, revision of sectoral strategy, and correction of implementation procedures.

Ultimately, the MTEF should be developed into a medium-term budgetary framework in order to give the annual budget a true medium-term outlook. To this end, the macroeconomic framework needs strengthening. Higher priority should be given to assurances of fiscal discipline and policy accountability. In this respect, the macroeconomic assumptions should be the exclusive responsibility of the MOF and the MTEF has to be prepared in a realistic approach. All ministries should produce a periodic progress report on their achievements and these reports should be available to Parliament at the time of budget discussion. Considering constraints in the capacity of the ministries, the objectives and indicators used to measure performance should be consistent with the availability of information on a timely basis. 
63. Expenditure arrears needs to be monitored and reported in order to enhance transparency in budget execution. To achieve steady budget implementation and avoid expenditure arrears, the current cash accounting system should be supplemented with an effective, ex ante, commitment control.

\section{Fiscal reporting}

64. Reports on budget execution should be further improved in terms of quality, timeliness, frequency, and coverage. The government should:

- Widen the coverage of its in-year reports on budget execution. These should include information on the activities of the revolving funds that remain outside the budget, other extra-budgetary funds such as the Police Welfare Fund, and other nonprofit institutions such as universities and boards. Initially, the government should aim at producing these reports no more than 60 days after the end of the quarter and progressively reduce this timing. These reports should be made available on the MOF website in both Nepali and English.

- $\quad$ Report, with the same frequency of the budget execution, on the consolidated position of its financial assets and on the debt stock. ${ }^{37}$ Such publication would include comprehensive information on valuation methods for assets and also information on the maturity structure of debt stock. The government should commence reporting the information initially from its existing memorandum records. In the medium term an accrual accounting system to record and report financial assets and liabilities could be considered.

- Include summary data on local government budget execution. In the first year, the inclusion should be limited to the collection, consolidation and reporting of annual data. From the second year the data collection and reporting should be the same as the in-year reporting on the central government fiscal operations.

\section{Public enterprises}

65. Systematic measures to strengthen transparency of the operation of PEs are urgently needed. The lack of proper accounting, auditing, and reporting by PEs is not only a major transparency problem but is also an important source of risk and uncertainty regarding future fiscal sustainability. The government should undertake the following measures:

- $\quad$ As a matter of urgency, all PEs should be externally audited according to international standards. Thereafter, the Boards of Directors and Chief Executives of these enterprises should be held accountable for producing and maintaining goodquality, regular, and timely accounts and subjecting them to audit. Legal action should be taken against errant officials. The quality of financial data should also be improved in terms of comprehensiveness and timeliness.

\footnotetext{
${ }^{37}$ It is important that information on the valuation method of these assets and liabilities be also disclosed.
} 
- Quasi-fiscal activities carried out by PEs should be estimated, analyzed and reported by the enterprise, subjected to scrutiny by the Corporation Coordination Division of the MOF, and included in the fiscal reports, particularly the budget and the annual financial statements.

- $\quad$ An analysis of the financial results of each PE should be published by the enterprise quarterly or semi-annually. The MOF should include a summary of these publications in its annual report on PEs.

- $\quad$ The Corporation Coordination Division of the MOF should be strengthened in order to ensure effective oversight of PEs.

\section{Accounting and audit}

66. The accounting system should be rationalized. The accounting system should serve as a basic tool for financial management. It should involve periodic reporting from which key data can be easily extracted. Staff suggest a phased move towards accrual accounting, with the first step being the adoption of accrual concepts for financial assets and liabilities. This will ensure that relevant information about these items is available for financial management and reporting. The budgetary legal framework needs to be adapted to accommodate these changes.

\section{A strong and effective audit is a critical component of fiscal transparency.}

Financial integrity requires publication of audit reports and the timely implementation of audit recommendations. The rectification of specific financial irregularities identified by the AG is particularly crucial. The last three annual Audit Reports submitted by the AG have not been published. The public can, therefore, only speculate as to the number and seriousness of financial irregularities waiting to be corrected. Staff emphasize that:

- It is necessary to institute and observe clear rules for timely publication of audit reports and appropriate action on the reported irregularities. These rules should be supported with effective deterrents for noncompliance. In his last budget speech the Minister of Finance acknowledged this problem and has undertaken to complete appropriate legal formalities quickly in order to ensure publication of all the unpublished reports of the AG.

- $\quad$ The staffing of the AG, in terms of quality and numbers, should be appropriate to the crucial role of audit in assuring financial integrity. The current level of staffing of the $\mathrm{AG}$ and the technical skills of the staff are clearly inadequate to meet the increasing demands placed on the AG.

- $\quad$ The AG should be in charge of the audit of all PEs, including those that are not fully owned by the government. Even if a private sector audit firm is appointed in particular cases, this should be at the discretion of the AG who should monitor the audit and take responsibility for it. International best practices indicate that AG should be responsible for auditing all PEs that are controlled by the government (more than 50 percent of ownership). 
- $\quad$ Staff training in the AG should be sharply increased so as to make available more audit staff technically capable of working effectively in relatively new areas such as performance auditing.

- $\quad$ The limited performance audit of large projects currently performed by the AG should be extended to all major projects.

68. The government should commit to publishing comprehensive information on its operations. Preferably, this commitment should be in the law and specify the timing and content of the publications. The main issues to be covered are indicated in this report.

69. Reform should follow a proper sequencing. The foregoing list of suggested reforms represents an ambitious program that cannot be fully realized in the short-term. Initially, the government should focus on issues that can be realized in the near future and have a positive impact on transparency.

70. The following measures should be implemented in the short-term (within a twelve month period) as they require relatively little preparatory work:

- Publicly announce a timeframe for publication of fiscal information, including an indication as to each publication's nature and contents.

- $\quad$ Enhance the integrity and credibility of the government's finances by timely publication of the AG's Report and implementation of follow-up mechanisms on recommendations.

- $\quad$ Make the macroeconomic assumptions of the budget realistic, explicit and specify broad fiscal policy objectives in the publicly available budget documents.

- $\quad$ Commence reforming economic classification of the budget to fully conform with GFSM 2001.

- Increase the MOF's ownership of the medium-term expenditure framework through enhanced participation in the development of the framework and full and exclusive responsibility in relation to the specification of the macroeconomic assumptions.

- Use a comprehensive definition of central government activities for better budget preparation, execution and reporting.

- Disclose information on the areas where contingent liabilities, tax expenditures and other quasi-fiscal activities occur, and provide corresponding budget estimates.

- Make all extra-budgetary activities subject to the general rules of accounting, audit, and publication.

- $\quad$ Disclose full information on the amount and structure of debt and financial assets from existing memorandum records. 
- Initiate measures for developing a commitment control system in order to report, control, and avoid expenditure arrears.

- Initiate training programs to increase the technical and operational abilities of staff and develop a program to improve human resource management practices.

\section{The following measures should be implemented in the medium-term (one to three years):}

- $\quad$ Strengthen the macro-fiscal unit of the MOF and allow external scrutiny of macroeconomic assumptions.

- $\quad$ Adopt a functional classification in the budget.

- Implement a commitment control system to report and control expenditure arrears.

- $\quad$ Strengthen internal audit functions.

- Integrate all extra-budgetary activities into the central government budget.

- $\quad$ Take steps so that fiscal activities can be reported on the basis of General Government, which includes all activities of central and local governments.

- $\quad$ Ensure the financial relationship between central government and local government is transparent and systematic, and define borrowing limits for local governments.

- $\quad$ Take steps to improve governance of PEs in order to, in particular, reduce the government's contingent liabilities.

- Introduce legal requirements for the publication of regular and timely reports, based on internationally accepted standards, of all public sector institutions.

- $\quad$ Eliminate quasi-fiscal activities and replace them, if necessary, with explicit subsidies.

- $\quad$ Reduce tax expenditures as much as possible.

- Introduce human resource management policies based on international best practice. 